\title{
Expression of an Activation Antigen, Mo3e, Associated With the Cellular Response to Migration Inhibitory Factor by HL-60 Promyelocytes Undergoing Monocyte- Macrophage Differentiation
}

\author{
Robert F. Todd, III, Martin J. Bury, and David Y. Liu \\ Simpson Memorial Research Institute, Division of Hematology/Oncology, Department of \\ Internal Medicine, University of Michigan Medical School, Ann Arbor (R.F.T., M.J.B.), and \\ Department of Rheumatology and Immunology, Brigham and Women's Hospital and the \\ Department of Medicine, Harvard Medical School, Boston (D.Y.L.)
}

\begin{abstract}
HL-60 promyelocytic cells acquire the surface expression of the Mo3e antigenic determinant after exposure to PMA or compounds that raise intracellular concentrations of cyclic AMP (dibutyryl cyclic AMP or a combination of cholera toxin and IBMX). The expression of M03e by these stimulated HL-60 cells coincides with the development of features of monocyte-macrophage differentiation (characteristic morphology, nonspecific esterase activity, and respiratory burst activity). During in vitro monocyte-macrophage differentiation, HL-60 cells become responsive to migration inhibitory factor (MIF); the MIF responsiveness of differentiated HL-60 cells is blocked by anti-Mo3e monoclonal antibody. These findings further support the relationship between the expression of Mo3e and the cellular response to MIF.
\end{abstract}

Key words: HL-60, macrophage differentiation, migration inhibitory factor, surface antigen expression

\section{INTRODUCTION}

We have previously reported the identification of a protease-sensitive plasma membrane antigen, Mo3e (p75, 50 by Western blot analysis) that is expressed by human monocytes after exposure of these cells in vitro to activating stimuli that include bacterial lipopolysaccharide (LPS), muramyl dipeptide, phorbol myristate acetate (PMA), and other biologically active phorbol compounds $[13,22]$. Anti-Mo3e monoclonal antibody blocks the response of human monocytes to migration inhibitory factor (MIF), indicating a functional association between the expression of Mo3e and (MIF) responsiveness [13]. We now report that pharmacological inducers of monocytemacrophage differentiation stimulate the expression of Mo3e by the human promyelocytic cell line, HL-60. Culture of HL-60 cells in medium containing PMA (10 $\mathrm{nM})$, dibutyryl cyclic AMP $(0.5 \mathrm{mM})$, or the combination of cholera toxin $(10 \mathrm{ng} / \mathrm{ml})$ and 3-isobutyl-1-methylxanthine (IBMX) (1 mM) provokes the acquired expression of Mo3e coincident with other features of monocyte-macrophage differentiation (monocytic morphology, nitroblue tetrazolium [NBT] reduction, nonspecific esterase [NSE] staining). The surface density of Mo3e (as measured by indirect immunofluorescence) increases as a function of culture duration (24-96 $\mathrm{hr}$ of incubation). Exposure of HL-60 cells to 1,25-dihydroxycholecalciferol $(500 \mathrm{nM})$ for $72-96 \mathrm{hr}$ stimulates a variable degree of Mo3e expression, while cells cultured in medium containing inducers of granulocytic differentiation (retinoic acid or DMSO) are Mo3e-negative. Previous studies have shown that PMA-stimulated HL-60 cells acquire responsiveness to MIF [14], and we now demonstrate that MIF responsiveness of PMA-induced HL- 60 cells is inhibited by anti-Mo3e monoclonal antibody. These observations indicate that the expression of MIF responseassociated antigen Mo3e is an inducible plasma membrane marker of monocytic cells derived from HL-60. The metabolic events that may be responsible for expression of Mo3e by activated human monocytic cells are discussed.

Received November 12, 1986; accepted December 1, 1986.

David Y. Liu's present address is Department of Immunology, Cetus Corp., Palo Alto, CA 94303.

Reprint requests: Robert F. Todd III, Simpson Memorial Institute, 102 Observatory Drive, Ann Arbor, MI 48109. 
MATERIALS AND METHODS

\section{Media and Reagents}

The following media and tissue culture additives were purchased from GIBCO Laboratories (Grand Island, NY): RPMI 1640 (320-1875), L-glutamine $200 \mathrm{mM}$ (3205030), and penicillin-streptomycin solution (600-5070). Fetal calf serum (FCS) was purchased from HyClone Laboratories (Logan, UT). Lots of RPMI 1640 and FCS were preselected for low endotoxin activity $(<0.1 \mathrm{ng} /$ $\mathrm{ml})$. The following reagents were purchased from Sigma Chemical Co. (St. Louis, MO): cholera toxin (C3012); $\mathrm{N}^{6}, 2^{\prime}$-O-dibutyryladenosine 3':5' -cyclic monophosphate (D0627); 3-isobutyl-1-methylxanthine (I5879); dimethyl sulfoxide (D5879); trans retinoic acid (R2625); $4 \beta$-phorbol 12-myristate 13-acetate (P8139); nitroblue tetrazolium (N6876): $\alpha$-naphthyl acetate (nonspecific) esterase kit (90-A1). 1,25-Dihydroxycholecalciferol (Ro21-5535) and human recombinant interferon- $\gamma$ were the gifts of Dr. M.R. Uskokovic and S. Pestka (Hoffmann-La Roche, Inc. Nutley, NJ), respectively. PMA was dissolved in DMSO $(1 \mathrm{mg} / \mathrm{ml})$ and stored at $-80^{\circ} \mathrm{C}$. Stock solutions of 1,25-dihydroxycholecalciferol and trans retinoic acid were prepared in $100 \%$ ethanol and stored at $-80^{\circ} \mathrm{C}$.

\section{Monoclonal Antibodies}

The generation and characterization of monoclonal antibodies anti-Mol (IgM), anti-Mo2 (IgM), anti-Mo3e (IgM), and anti-Plt 1 (IgM) have been described [22,24, $26,27]$. Antibody containing ascites was used in all immunofluorescence assays.

\section{HL-60 Cell Line}

The human promyelocytic cell line HL-60 [2] was obtained from Dr. Edward Prochownik (University of Michigan) and grown in RPMI 1640-FCS (RPMI 1640 medium supplemented with $10 \%$ FCS, L-glutamine 2 $\mathrm{mM}$, penicillin $50 \mathrm{U} / \mathrm{ml}$, and streptomycin $50 \mu \mathrm{g} / \mathrm{ml}$ ). The cell line was maintained in log growth phase by thrice-weekly feeding.

\section{Culture of HL-60 With Various Differentiating Reagents}

In experiments designed to assess the effect of various differentiating agents on HL-60 Mo3e expression, cells were cultured $\left(3-4 \times 10^{5} / \mathrm{ml}\right)$ in 60 - or $100-\mathrm{mm}$ plastic culture dishes (Falcon Plastic, Oxnard, CA) containing fresh 1640-FCS to which various chemical agents were added ( to a total volume of 6 or $10 \mathrm{ml}$, respectively). The final concentrations of DMSO or ethanol, which was used as an initial diluent for certain reagents as indicated earlier, did not exceed $0.4 \%$, and cultures containing appropriate quantities of DMSO or ethanol were run in parallel to control for any minor diluent effects. Cultures were incubated at $37^{\circ} \mathrm{C}$ in a humidified atmosphere of $5 \% \mathrm{CO}_{2}$ in air for 24 to $96 \mathrm{hr}$. At the end of culture, medium containing nonadherent cells was removed and combined with adherent cells harvested by exposure to $0.5 \mathrm{mM}$ EDTA followed by scraping. These recovered nonadherent and adherent cells were washed, counted (viability assessed by trypan blue exclusion), and resuspended in phosphate-buffered saline supplemented with glucose $1 \mathrm{mg} / \mathrm{ml}$ and $2.5 \%$ human pooled AB serum) at a concentration of 5 to $20 \times 10^{6}$ cells per $\mathrm{ml}$ for subsequent immunofluorescence staining.

\section{Immunofluorescence Flow Cytometric Analysis}

Aliquots containing 0.5 to $2.0 \times 10^{6}$ cells were subjected to indirect immunofluorescence staining for the expression of Mo3e or Mo2 relative to background staining using an IgM-negative control reagent (anti-PIt 1) as described [22]. Intact (live) cells were selected by gating (log forward angle versus log right angle light scatter). Immunofluorescence intensity as a measure of relative antigen expression was analyzed on a Coulter Electronics (Hialeah, FL) EPICS C flow cytometer with the use of a logarithmic amplifier. The channel number (log scale) representing the mean fluorescence intensity (major fluorescence peak) of 5,000 cells exposed to either experimental or isotype-identical negative control antibodies was determined. The corresponding linear fluorescence intensity channel was calculated from a logarithmic-linear calibration formula [17]. Specific fluorescence intensity represents the computed mean channel number ( 0 to 296 channels, linear scale) of cells stained with the experimental monoclonal antibody minus the mean channel of cells stained with the negative control reagent [22].

\section{Assessment of Morphological, Histochemical, and Metabolic Changes Associated With HL-60 Differentiation}

In parallel to immunofluorescence analysis of Mo3e antigen expression, HL-60 cells cultured in the presence of differentiating stimuli were assessed for changes in cellular morphology, the acquisition of nonspecific esterase activity [30], and the capacity to reduce NBT. The morphological appearance of cells was assessed by light microscopic examination of Wright-Giemsa-stained cytocentrifuge smears; nonspecific esterase activity was determined according to the Sigma kit protocol ( $\$ 90$ A1). The ability to reduce NBT was assayed by incubating $5 \times 10^{5}$ cells in $1 \mathrm{ml}$ PBS containing $0.5 \mathrm{mg} \mathrm{NBT}$ and $1 \mu \mathrm{g}$ PMA ( $1 \mu \mathrm{l}$ of a $1 \mathrm{mg} / \mathrm{ml}$ stock solution in DMSO) for $20 \mathrm{~min}$ at $37^{\circ} \mathrm{C}$. Cytocentrifuge smears were then prepared, and the number of cells containing blue-black deposits was counted [21]. A minimum of 200 cells were examined per determination.

\section{MIF Assay}

The response of PMA-stimulated or control HL-60 cells to MIF was expressed as the percentage of migra- 
tion inhibition according to the following formula [13]: $\%$ inhibition of migration $=1-$ (average migration of cells exposed to MIF/average migration of cells exposed to control medium) $\times 100 \%$. Migration of HL-60 cells in the presence or absence of MIF-containing supernatants was assessed in a microcapillary assay as previously described [14]. The effect of anti-Mo3e monoclonal antibody on the response of HL-60 cells to MIF was determined by performing the microcapillary assay in the presence of medium containing a saturating concentration of anti-Mo3e ascites fluid as previously reported [13].

\section{One-Dimensional Electrophoresis and Western Immunoblotting}

One-dimensional polyacrylamide gel electrophoresis in the presence of sodium dodecyl sulfate (SDS-PAGE) was performed according to the procedure of Laemmli [12]. HL-60 cells were cultured for 16-24 hr in 1640-FCS in the absence or presence of either $100 \mathrm{nM}$ PMA or 0.5 mM dibutyryl cyclic AMP. The cells were harvested, washed twice, and solubilized in lysis buffer $(10 \mathrm{mM}$ tris- $\mathrm{HCl}$ buffer, $\mathrm{pH} 7.4,0.5 \%$ Nonidet $\mathrm{P}-40,150 \mathrm{mM}$ $\mathrm{NaCl}, 10 \mathrm{mM}$ leupeptin, $3 \mathrm{mM}$ iodoacetamide, $1 \mathrm{mM}$ phenylmethylsulfonylfluoride) at $4^{\circ} \mathrm{C}$ for 30 min before electrophoresis. Proteins were electrophoretically transferred onto nitrocellulose sheets by the Western blotting technique [28] and then probed with anti-Mo3e antibody and the horseradish peroxidase Vectastain kit (Vector Laboratories, Burlingame, CA). The M.W. reference proteins used for SDS-PAGE were phosphorylase-b, bovine serum albumin, ovalbumin, and carbonic anhydrase.

\section{RESULTS}

\section{Expression of Mo3e by HL-60 Cells Cultured in Medium Containing Certain Inducers of Monocytic Differentiation}

We have previously reported that HL-60 cells cultured in medium containing $4 \beta$-phorbol 12 -myristate 13 -acetate (PMA) under conditions that induce monocyte-macrophage differentiation acquire the surface expression of Mo3e [23]. Experiments were performed to determine if other inducers of HL-60 differentiation would stimulate the expression of surface Mo3e. As recently reported by Chaplinski and Niedel [4,5], culture of HL-60 cells in medium containing agents that stimulate the production of intracellular cyclic adenosine monophosphate (cyclic AMP) results in differentiation along the monocyte-macrophage pathway. Exposure of HL-60 cells to dibutyryl cyclic AMP $(0.5 \mathrm{mM})$, cholera toxin $(10 \mathrm{ng} / \mathrm{ml})$, 3isobutyl-1-methylxanthine (IBMX, $1 \mathrm{mM}$ ), or combinations of these agents (eg., cholera toxin plus IBMX) for 24-96 hr resulted in the acquired expression of Mo3e (Fig. 1 and Table 1) that coincided with the development of features of monocyte-macrophage differentiation: coexpression of the monocyte surface marker, Mo2 (gp 55) (Fig. 2), monocyte-macrophage morphology, $\alpha$-naphthyl acetate (nonspecific) esterase, and the capacity to reduce nitroblue tetrazolium (Fig. 3). While dibutyryl cyclic AMP was sufficient to induce Mo3e expression in excess of that stimulated by PMA, cholera toxin (an activator of adenylate cyclase) and IBMX (a cyclic AMP phosphodiesterase inhibitor) were synergistic in stimulating comparable levels of surface Mo3e expression (Table 1). Other pharmacological inducers of cyclic AMP production such as isoproterenol or prostaglandin $E_{2}$ were less active in stimulating Mo3e expression (not shown). Exposure of HL-60 cells to human recombinant gamma interferon $(10-1,000 \mathrm{U} / \mathrm{ml})$ for $1-4$ days failed to induce detectable levels of surface Mo3e expression (not shown). Culture of HL-60 cells in medium containing 1,25-dihydroxycholecalciferol $(500 \mathrm{nM})$ for 1-4 days induced prominent features of monocyte-macrophage differentiation, but the degree of surface Mo3e expression by these cells was variable (one subline of HL-60 was, as previously reported [23], consistently negative for Mo3e expression despite other features of monocyte-macrophage differentiation). HL-60 cells exposed to inducers of granulocytic differentiation such as trans retinoic acid $(1 \mu \mathrm{M})$ or DMSO $(1.2 \%)$ failed to stimulate surface Mo3e expression (not shown).

\section{Identification of Mo3e in Lysates of HL-60 Cells by Western Blotting}

Western blot analysis of lysates from control and PMAstimulated HL-60 cells probed with anti-Mo3e monoclonal antibody demonstrated two polypeptides of 75 and 50 $\mathrm{kD}$. Consistent with previous observations in control and PMA-stimulated monocytes $[13,25]$, the $75 \mathrm{kD}$ polypeptide was detectable in lysates from both unstimulated and PMA-cultured HL-60 cells, while the $50 \mathrm{kD}$ band was consistently seen only in the lysates of PMA-stimulated cells (Fig. 4). Similar results were observed after stimulation of HL-60 cells with dibutyryl cyclic AMP (not shown).

\section{Inhibition of MIF Response of PMA-Stimulated HL- 60 Cells by Anti-Mo3e Monoclonal Antibody}

As previously reported [13], anti-Mo3e monoclonal antibody blocks the response of human peripheral blood monocytes to MIF indicating that the expression of Mo3e is functionally associated with the response to MIF. Consistent with this notion is the fact that Mo3e-negative unstimulated HL-60 cells are unresponsive to MIF, but acquire responsiveness to MIF after exposure to PMA [14] under conditions that stimulate Mo3e expression. As shown in Table 2, the MIF response of PMA-cultured HL-60 cells is blocked by anti-Mo3e antibody. 

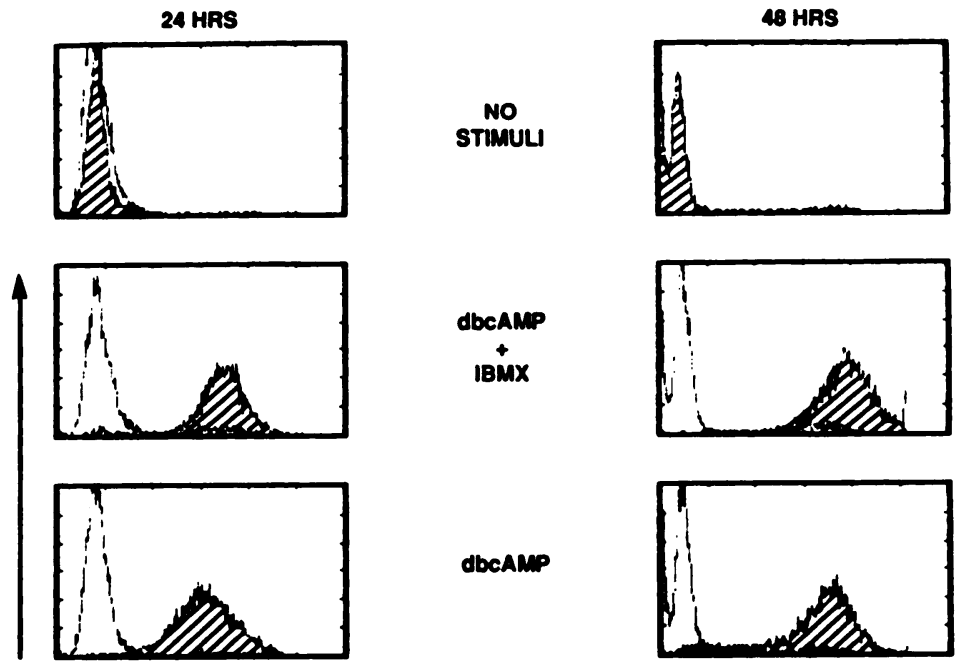

dbcaMP IBMX
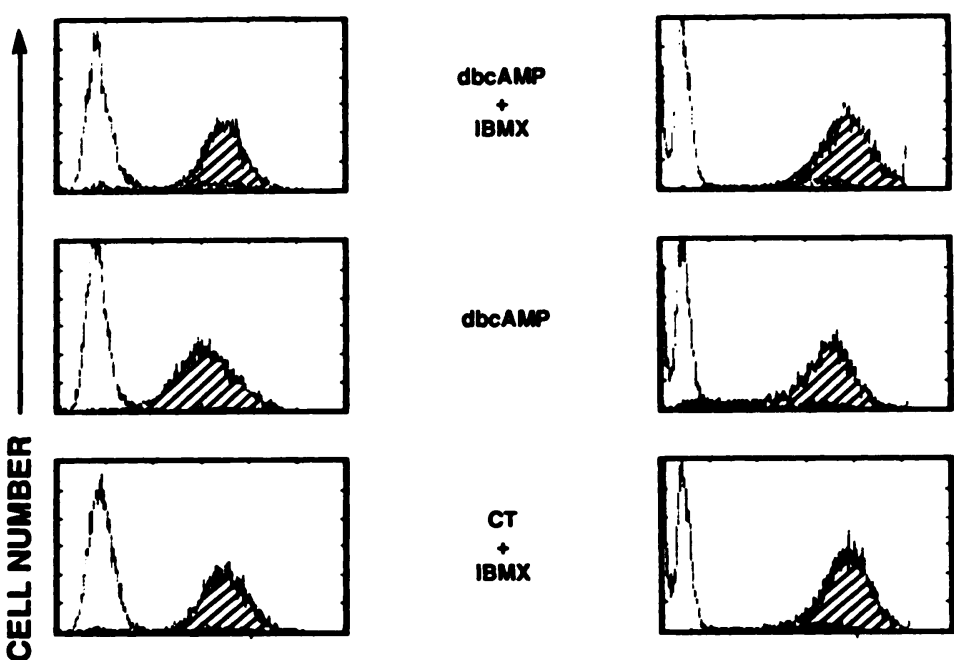

CT
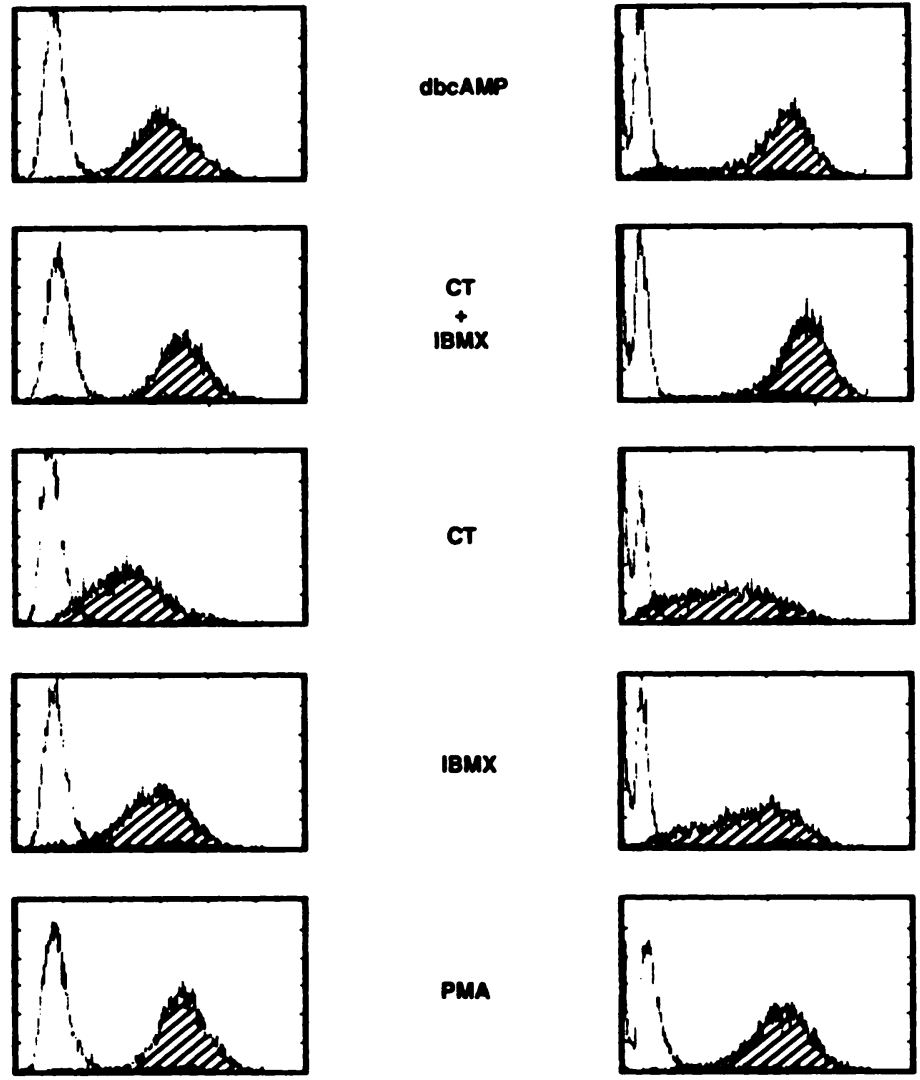

$\operatorname{IBMx}$

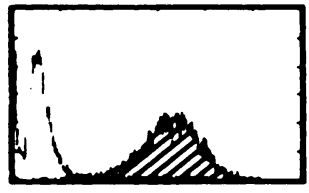

IMMUNOFLUORESCENCE INTENSITY (LOG 10$)$

Fig. 1. Stimulation of surface M03e expression by HL-60 cells after culture in medium containing PMA or agents that increase intracellular cyclic AMP. HL-60 cells $\left(3 \times 10^{5} / \mathrm{ml}\right)$ were cultured for 24 or $48 \mathrm{hr}$ in medium containing the indicated stimull (same concentrations as in Table 1). After culture, the cells were stained by indirect immunofluorescence for the expression of Mo3e (cross-hatched histograms) versus control IgM antibody binding (open histograms).

\section{DISCUSSION}

Mo3e is a protease-sensitive antigenic determinant that is selectively expressed by human peripheral blood monocytes and U-937 monoblasts after exposure of these cells in vitro to several activating stimuli $[13,22]$. Since unactivated monocytic cells express little or no surface Mo3e that is detectable by indirect immunofluorescence, the acquisition of Mo3e represents an immunological marker of phagocyte activation [22]. The physiological significance of Mo3e expression is suggested by the results of antibody-blocking experiments in which the monocyte response to MIF is inhibited by incubation of monocytes in medium containing anti-Mo3e monoclonal antibody (other IgM anti-monocyte reagents having no inhibitory effect) [13]. Whether Mo3e represents an epi- 
TABLE 1. PMA and Agents That Increase Intracellular Cyclic AMP Stimulate the Surface Expression of Mo3e by HL-60 Cells

\begin{tabular}{|c|c|c|c|c|c|c|c|}
\hline \multirow[b]{3}{*}{ Stimulus } & \multicolumn{7}{|c|}{ Specific immunofluorescence intensity } \\
\hline & \multicolumn{2}{|c|}{ Exp. $1^{b}$} & \multicolumn{3}{|c|}{$\operatorname{Exp} 2^{b}$} & \multicolumn{2}{|c|}{ Exp. $3^{b}$} \\
\hline & $24 \mathrm{hr}$ & $48 \mathrm{hr}$ & $48 \mathrm{hr}$ & $72 \mathrm{hr}$ & $96 \mathrm{hr}$ & $48 \mathrm{hr}$ & $72 \mathrm{hr}$ \\
\hline - & $\begin{array}{l}0.12^{c} \\
(0.52)^{d}\end{array}$ & $\begin{array}{l}0.04 \\
(0.33)\end{array}$ & $\begin{array}{l}0.34 \\
(0.63)\end{array}$ & $\begin{array}{l}0.05 \\
(0.54)\end{array}$ & $\begin{array}{l}0.03 \\
(1.19)\end{array}$ & $\begin{array}{l}0.10 \\
(0.64)\end{array}$ & $\begin{array}{l}0.03 \\
(0.61)\end{array}$ \\
\hline dbcAMP & $\begin{array}{l}14.93 \\
(0.59)\end{array}$ & $\begin{array}{l}25.15 \\
(0.35)\end{array}$ & $\begin{array}{l}35.84 \\
(2.54)\end{array}$ & $\begin{array}{l}35.41 \\
(0.79)\end{array}$ & $\begin{array}{l}67.70 \\
(1.26)\end{array}$ & $\begin{array}{l}19.71 \\
(0.48)\end{array}$ & $\begin{array}{l}43.57 \\
(0.84)\end{array}$ \\
\hline dbcAMP + IBMX & $\begin{array}{l}27.21 \\
(0.63)\end{array}$ & $\begin{array}{l}48.12 \\
(0.36)\end{array}$ & $\begin{array}{l}34.78 \\
(3.60)\end{array}$ & $\begin{array}{l}40.03 \\
(0.66)\end{array}$ & $\begin{array}{l}133.72 \\
(1.26)\end{array}$ & $\begin{array}{l}53.86 \\
(0.63)\end{array}$ & $\begin{array}{l}55.22 \\
(0.77)\end{array}$ \\
\hline CT & $\begin{array}{l}4.45 \\
(0.52)\end{array}$ & $\begin{array}{l}3.50 \\
(0.32)\end{array}$ & $\begin{array}{l}7.06 \\
(0.64)\end{array}$ & $\begin{array}{l}2.74 \\
(0.47)\end{array}$ & $\begin{array}{l}5.07 \\
(1.22)\end{array}$ & $\begin{array}{l}4.82 \\
(0.61)\end{array}$ & $\begin{array}{l}5.12 \\
(0.47)\end{array}$ \\
\hline $\mathrm{CT}+\mathrm{IBMX}$ & $\begin{array}{l}26.38 \\
(0.66)\end{array}$ & $\begin{array}{l}44.08 \\
(0.33)\end{array}$ & $\begin{array}{l}32.59 \\
(4.69)\end{array}$ & $\begin{array}{l}34.48 \\
(0.68)\end{array}$ & $\begin{array}{l}91.08 \\
(1.26)\end{array}$ & $\begin{array}{l}45.05 \\
(0.68)\end{array}$ & $\begin{array}{l}49.24 \\
(0.68)\end{array}$ \\
\hline IBMX & $\begin{array}{l}11.35 \\
(0.59)\end{array}$ & $\begin{array}{l}7.15 \\
(0.33)\end{array}$ & $\begin{array}{l}16.97 \\
(3.82)\end{array}$ & $\begin{array}{l}10.34 \\
(0.59)\end{array}$ & $\begin{array}{l}14.71 \\
(1.30)\end{array}$ & $\begin{array}{l}8.68 \\
(0.77)\end{array}$ & $\begin{array}{l}4.89 \\
(0.54)\end{array}$ \\
\hline PMA & $\begin{array}{l}26.45 \\
(0.59)\end{array}$ & $\begin{array}{l}19.79 \\
(0.40)\end{array}$ & $\begin{array}{l}35.61 \\
(6.28)\end{array}$ & $\begin{array}{l}23.58 \\
(1.19)\end{array}$ & $\begin{array}{l}17.39 \\
(1.69)\end{array}$ & $\begin{array}{l}25.02 \\
(1.03)\end{array}$ & $\begin{array}{l}22.39 \\
(0.97)\end{array}$ \\
\hline DMSO & $\begin{array}{l}0.00 \\
(0.56)\end{array}$ & $\begin{array}{l}0.03 \\
(0.35)\end{array}$ & $\begin{array}{l}2.70 \\
(0.70) \\
\end{array}$ & $\begin{array}{l}0.14 \\
(0.52)\end{array}$ & $\begin{array}{l}0.04 \\
(1.26)\end{array}$ & $\begin{array}{l}0.10 \\
(0.51)\end{array}$ & $\begin{array}{l}0.16 \\
(0.56) \\
\end{array}$ \\
\hline
\end{tabular}

${ }^{\mathrm{a}} \mathrm{HL}-60$ cells $\left(3 \times 10^{5} / \mathrm{ml}\right)$ were cultured for the indicated times in medium containing dibutyryl cyclic AMP (dbcAMP, 0.5 mM), 3-isobutyl1 -methylxanthine (IBMX, $1 \mathrm{mM}$ ), cholera toxin (CT, $10 \mathrm{ng} / \mathrm{ml})$, phorbol myristate acetate (10 $\mathrm{nM}$ ), dimethylsulfoxide diluent (DMSO, $0.00062 \% \mathrm{v} / \mathrm{v})$, or no additives $(-)$. After culture, the cells were stained by indirect immunofluorescence for the expression of Mo3e.

bPMT setting in experiments 1 and 2 was 1100 ; in experiment $3,1150 \mathrm{mV}$.

${ }^{c}$ Numbers indicate the specific fluorescence intensity.

dNumbers in parentheses indicate the fluorescence intensity of cells (computed mean linear channel numbers) stained with negative control antibody (this represents the background immunofluorescence that was subtracted from the experimental immunofluorescence values to yield the specific fluorescence intensity).

tope within the MIF ligand binding domain of the MIF receptor or an epitope of a molecule with an accessory role in the response to MIF remains to be determined. In this report, we extend our previous observations relating to the induction of Mo3e expression and its relationship to MIF responsiveness by an examination of HL- 60 promyelocytic cells during pharmacologically induced myeloid differentiation.

In 1979, Rovera and coworkers reported that exposure of HL-60 cells to PMA induced their transformation into cells that exhibited many features of monocyte-macrophage differentiation [20]. Other investigators found that several additional agents could induce HL-60 monocytemacrophage differentiation: other biologically active phorbol compounds [29], diacylglycerol compounds [7], lectin-stimulated lymphokine supernatants [8], human gamma interferon [6,11], 1,25-dihydroxycholecalciferol $[15,16]$, and compounds that stimulate the generation of intracellular cyclic AMP $[4,5]$. Conversely, differentiation of HL-60 cells along the granulocytic pathway could be stimulated by exposure to DMSO [3] or to retinoic acid [1]. Thus, the transformation of HL-60 cells by selective inducers of monocytic or granulocytic maturation serves as an in vitro model of human myeloid differentiation. Accompanying the changes in cellular morphology, histochemistry, and function that occur dur- ing HL-60 differentiation, are changes in surface antigen expression that reflect differentiation at the plasma membrane level $[9,10,19,24]$. These observations led us to examine HL-60 cells for the acquired expression of the MIF-associated determinant Mo3e. Unstimulated HL-60 cells are negative for the surface expression of Mo3e as measured here by indirect immunofluorescence. However, exposure of HL-60 to PMA or to agents that raise the intracellular concentration of cyclic AMP stimulates surface Mo3e expression under conditions resulting in features of monocytic differentiation (as assessed by characteristic morphology, histochemistry, and the acquisition of respiratory burst activity). Either cell-permeant dibutyryl cyclic AMP or the combination of cholera toxin (an activator of adenylate cyclase) and IBMX (an inhibitor of cyclic AMP phosphodiesterase) induce the expression of Mo3e to a surface density that (on a per cell basis) exceeds that provoked by optimally stimulatory concentrations of PMA. Surface Mo3e expression becomes evident within $24 \mathrm{hr}$ of exposure to these agents (preceding other features of monocytic differentiation) and generally increases as a function of time. Exposure of HL-60 cells to recombinant gamma interferon had no positive effect in inducing Mo3e expression, while culture of cells in medium containing 1,25-dihydroxycholecalciferol produced variable degrees of Mo3e expression. Retinoic 


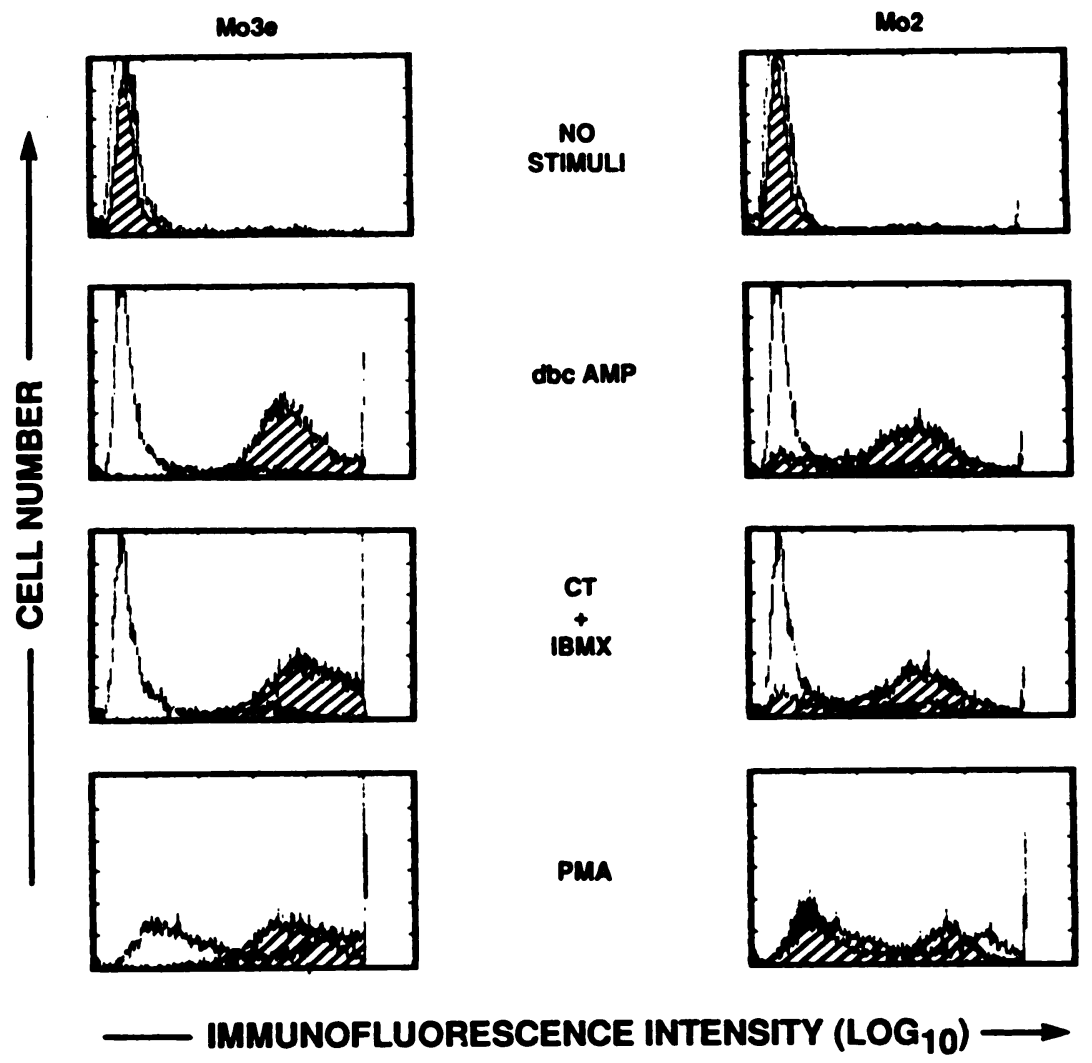

Fig. 2. Comparison between the expression of M03e and the monocyte marker Mo2 (gP 55) by HL-60 cells stimulated by agents that increase intracellular cyclic AMP and by PMA. HL-60 cells $\left(3 \times 10^{5} / \mathrm{ml}\right)$ were cultured for $72 \mathrm{hr}$ in medium containing the indicated stimuli (same concentrations as in Table 1). After culture the cells were stained by indirect immunofiuorescence for the expreseion of Mo3e (cross-hatched histograms under the Mo3e column), Mo2 (cross-hatched histograms under the Mo2 column), versus control IgM antibody binding (open histograms).

acid and DMSO, inducers of granulocytic differentiation, failed to stimulate Mo3e expression.

In a previous report [23], we suggested that the induction of Mo3e expression by monocytic cells is a cellular response to activation of protein kinase $\mathrm{C}$ and calcium mobilization, metabolic consequences of receptor-mediated phosphatidylinositol degradation with the generation of 1,2-diacylglycerol (the endogenous activator of protein kinase C) and inositol trisphosphate (a promoter of calcium release from intracellular stores) [see 18 for review]. This notion was based on the stimulatory effect of agents that mimic the effect of endogenous 1,2-diacylglycerol (PMA and other biologically active phorbol compounds, mezerein, and synthetic cell-permeant diacylglycerols) either alone or in concert with calcium ionophore, ionomycin, in inducing surface Mo3e expression [23]. Consistent with this idea was the inhibitory effect of various inhibitors of protein kinase $C$ activation or calcium mobilization on Mo3e expression stimulated by PMA [23]. As suggested by this report, the surface expression of Mo3e may also be a consequence of the generation of increased concentrations of intracellular cyclic AMP either as a result of the incorporation of exogenous cell-permeable cyclic AMP (dibutyryl cyclic AMP) or stimulation by the adenylate cyclase agonist, cholera toxin, in synergy with an inhibitor of cyclic AMP degradation (IBMX). Consistent with this idea are the results of experiments in which culture of peripheral blood monocytes for $24 \mathrm{hr}$ in medium containing cholera toxin, dibutyryl cyclic AMP, or IBMX stimulated Mo3e expression to a surface density that approaches that stimulated by LPS (Todd, R.F., unpublished). It would thus appear that either the phosphatidylinositol or adenylate cyclase signal transduction pathways may promote cellular effector responses that include surface Mo3e expression.

The structural features of Mo3e seen in unstimulated and PMA or dibutyryl cyclic AMP-activated HL-60 cells 


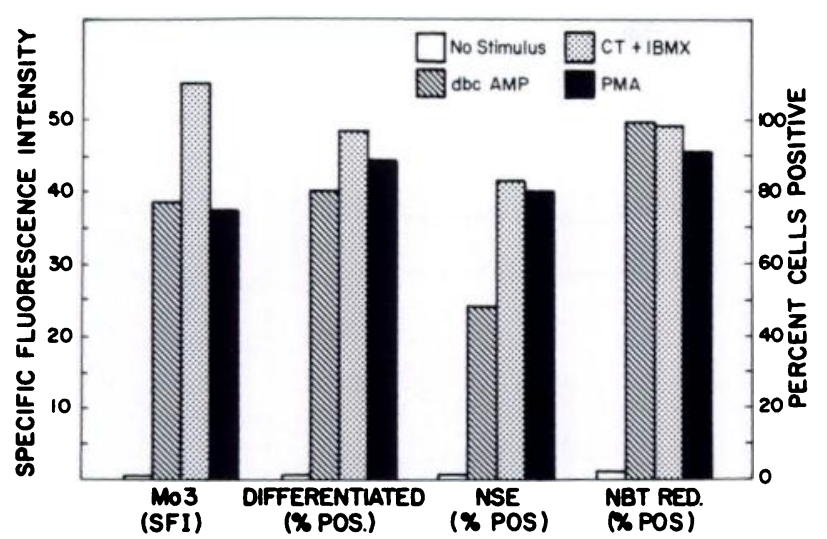

Fig. 3. Comparison between surface Mo3e expression and features of monocyte-macrophage differentiation. HL-60 cells $\left(2.5 \times 10^{5} / \mathrm{ml}\right)$ were cultured for $72 \mathrm{hr}$ in medium containing the indicated stimuli (same concentrations as in Table 1). After culture the cells were stained by indirect immunofiuorescence for the expression of Mo3e (as measured by specific fluorescence intensity [SFI]); separate aliquots were assayed for reduction of nitroblue tetrazolium (NBT), $\alpha$-naphthyl acetate (nonspecific) esterase activity (NSE), and morphological characteristics after Wright-Giemsa staining of cytocentrifuge emears, and scored as the percentage positive of the 200 cells counted. Characteristics of "differentiated" cells included an increase in the amount of cytoplasm with the appearance of a ruffied, irregular shape and a loss of azurophilic cytoplasmic granules (characteristic of promyelocytes).

are similar to those observed in human monocytes $[13,25]$. A $75 \mathrm{kD}$ polypeptide is detectable in lysates of either unstimulated or PMA-activated cells (with no obvious quantitative change after activation). In the lysates of activated cells, a second polypeptide of $50 \mathrm{kD}$ is consistently seen. While the relationship between $\mathrm{p} 75$ and p50 is not as yet clear, p50 may represent the determinant that is detectable by surface antibody binding to intact cells (an idea that is consistent with the results of preliminary immunoprecipitation experiments [Todd, unpublished]).

A relationship between surface Mo3e expression and MIF responsiveness is further supported by the parallel acquisition of Mo3e expression and MIF responsiveness by PMA-stimulated HL-60 cells. Mo3e-negative, unstimulated HL-60 cells are unresponsive to MIF, but after 24-hr exposure to PMA under conditions that promote the surface expression of Mo3e, HL-60 cells acquire responsiveness to MIF [14] that can be blocked by antiMo3e monoclonal antibody. While these results are consistent with the idea that Mo3e represents the surface receptor for MIF, the effect of anti-Mo3e antibody on the binding of radiolabeled purified MIF lymphokine (currently unavailable) must be determined to directly test this hypothesis.
TABLE 2. Response of PMA-Stimulated HL-60 Cells to Migration Inhibitory Factor (MIF) and Its Inhibltion by AntiMo3e Monoclonal Antibody

\begin{tabular}{lccc}
\hline & \multicolumn{3}{c}{$\begin{array}{c}\text { Percentage inhibition } \\
\text { of migration }\end{array}$} \\
\cline { 2 - 4 } $\begin{array}{l}\text { Exp. } \\
\text { No. }\end{array}$ & HL-60 & HL-60/PMA & $\begin{array}{c}\text { HL-60/PMA } \\
+ \text { anti-Mo3e }\end{array}$ \\
\hline 1 & 0 & 42 & ND \\
2 & 1 & 43 & $15(65)^{\mathrm{c}}$ \\
3 & 0 & 48 & $0(100)$ \\
4 & 0 & 43 & $0(100)$ \\
5 & 0 & 35 & $4(89)$ \\
6 & 0 & 40 & $0(100)$ \\
\hline
\end{tabular}

${ }^{\text {a } H L-60}$ cells $\left(5 \times 10^{5} / \mathrm{ml}\right)$ were cultured for $16-20 \mathrm{hr}$ in medium containing PMA $100 \mathrm{nM}$.

bIF assay performed in medium containing anti-Mo3e monoclonal antibody (1/250 dilution of ascites). An irrelevant negative control IgM monoclonal antibody (anti-Mol) had no inhibitory effect.

${ }^{c}$ Numbers in parentheses are percentage inhibition of the MIF response.

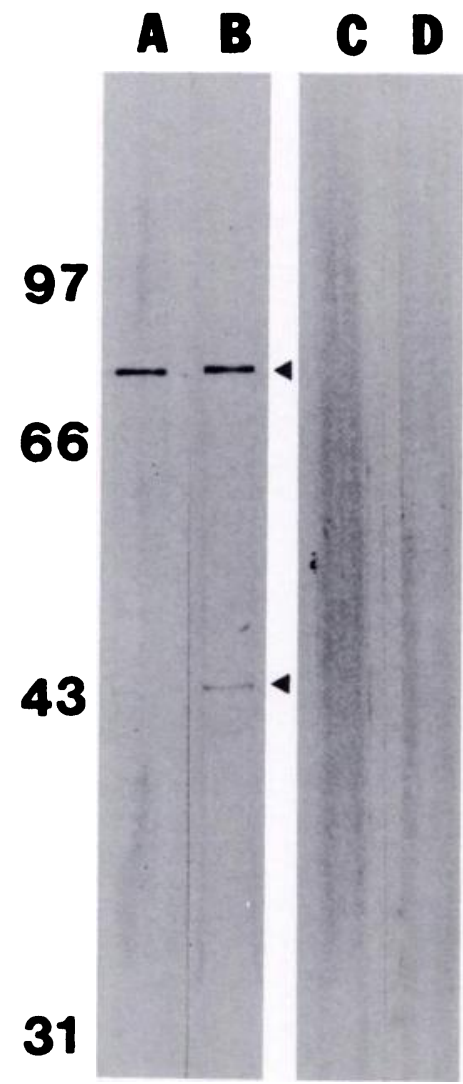

Fig. 4. Western blot analyels of HL-60 NP-40 cellular lysates. Lane A represents the Westem blot of unstimulated HL-60 cells. Lane B represents the Western blot of HL-60 cells cultured for $22 \mathrm{hr}$ in medium containing PMA $100 \mathrm{nM}$. Both lanes were probed with anti-Mo3e monoclonal antibody and then rabbit anti-mouse IgM (blotin conjugate) and with avidin, and finally with blotin-horeeradish peroxidase. Lysates from unstimulated and PMA-stimulated HL-60 cells initially probed with a negative control IgM monoclonal antibody (anti-Mo1) were negative (lanes C and D, respectively). The molecular weight markers are shown on the left. 


\section{ACKNOWLEDGMENTS}

The authors acknowledge the expert technical assistance of Ms. Joy Y. Ree and Mr. David A. Brott, and the secretarial support of Mr. Dennis C. Dicks. The work was supported by NIH grants CA42246-01 (R.F.T.), CA39064-02 (R.F.T.), and CA40550 (D.Y.L.), and by NSF grant DCB-8510469 (D.Y.L.).

\section{REFERENCES}

1. Breitman, T.R., Selonick, S.E., and Collins, S.J. Induction of differentiation of the human promyelocytic cell line (HL-60) by retinoic acid. Proc. Natl. Acad. Sci. U.S.A. 77, 2936, 1980.

2. Collins, S.J., Gallo, R.C., and Gallagher R.E. Continuous growth and differentiation of human leukemic cells in suspension culture. Nature 270, 347, 1977.

3. Collins, S.J., Ruscetti, M.W., Gallagher, R.E., and Gallo, R.C. Terminal differentiation of human promyelocytic leukemia cells induced by dimethyl sulfoxide and other polar compounds. Proc. Natl. Acad. Sci. U.S.A. 75, 2458, 1978.

4. Chaplinski, T.J., and Niedel, J.E. Cyclic nucleotide-induced maturation of human promyelocytic leukemia cells. J. Clin. Invest. 70, 953, 1982.

5. Chaplinski, T.J., and Niedel, J.E. Cyclic AMP levels and cellular kinetics during maturation of human promyelocytic leukemia cells. J. Leuk. Biol. 39, 323, 1986.

6. Dayton, E.T., Matsumoto-Kobayashi, M., Perussia, B., and Trinchieri, G. Role of immune interferon in the monocytic differentiation of human promyelocytic cell lines induced by leukocyte conditioned medium. Blood 66, 583, 1985.

7. Ebeling, J.G., Vandenbark, G.R., Kuhn, L.J., Ganong, B.R., Bell, R.M., and Niedel, J.E. Diacylglycerols mimic phorbol diester induction of leukemic cell differentiation. Proc. Natl. Acad. Sci. U.S.A. 82, 815, 1985.

8. Elias, L., Wogenrich, F.J., Wallace, J.M., and Longmire, J. Altered pattern of differentiation and proliferation of HL-60 promyelocytic leukemia cells in the presence of leucocyte conditioned medium. Leuk. Res. 4, 301, 1980.

9. Graziano, R.F., Ball, E.D., and Fanger, M.W. The expression and modulation of human myeloid-specific antigens during differentiation of the HL-60 cell line. Blood 58, 836, 1983.

10. Griffin, J.D., Ritz, J., Nadler, L.M., and Schlossman, S.F. Expression of myeloid differentiation antigens on normal and malignant myeloid cells. J. Clin. Invest. 68, 932, 1981.

11. Harris, P.E., Ralph, P., Gabrilove, J., Welte, K., Karmali, R., and Moore, M.A.S. Distinct differentiation-including activities of $\boldsymbol{\gamma}$-interferon and cytokine factors acting on the human promyelocytic leukemia cell line HL-60. Cancer Res. 45, 3090, 1985.

12. Laemmli, U.K. Cleavage of structural proteins during the assembly of the head of bacteriophage T4. Nature 227, 680, 1970.

13. Liu, D.Y., and Todd, R.F. III. A monoclonal antibody specific for a monocyte-macrophage membrane component blocks the human monocyte response to migration inhibitory factor. J. Immunol. 137, 448, 1986.

14. Liu, D.Y., Yu, S.-F., Remold, H.G., and David, J.R. Macrophage glycolipid receptors for human migration inhibitory factor
(MIF): Differented HL-60 cells exhibit MIF responsiveness and express surface glycolipids which both bind MIF and convert nonresponsive cells to responsiveness. Cell. Immunol. 90, 605, 1985.

15. Mangelsdorf, D.J., Koeffler, H.P., Donaldson, C.A. Pike, J.W., and Haussler, M.R. 1,25-Dihydroxyvitamin $D_{3}$ induced differentiation in a human promyelocytic leukemia cell line (HL-60): Receptor-mediated maturation to macrophage:like cells. J. Cell. Biol. 98, 391, 1984.

16. Miyawa, C., Abe, E., Kuribayashi, T., Tanaka, H., Kouno, K., Nishii, $Y$., and Suda, T. 1,25-Dihydroxyvitamin $D_{3}$ induces differentiation of human myeloid cells. Biochem. Biophys. Res. Commun. 102, 937, 1981.

17. Muirhead, K.A., Schmitt, T.C., and Muirhead, A.R. Determination of linear fluorescence intensity from flow cytometric data accumulated with logarithmic amplifiers. Cytometry 3, 251, 1983.

18. Nishizuka, Y. Studies and perspectives of protein kinase C. Science 233, 305, 1986.

19. Perussia, B., Lebman, D., Ip, S.H., Rovera, G., and Trinchieri, G. Terminal differentiation surface antigens of myelomonocytic cells are expressed in human promyelocytic leukemia cells (HL60) treated with chemical inducers. Blood 58, 836, 1981.

20. Rovera, G., Santoli, D., and Damsky, C. Human promyelocytic leukemia cells in culture differentiate into macrophage-like cells when treated with phorbol diesters. Proc. Natl. Acad. Sci. U.S.A. 76, 2779, 1979.

21. Segal, A.W. Nitroblue-tetrazolium tests. Lancet 2, 1248, 1974.

22. Todd, R.F., Alvarez P.A., Brott, D.A., and Liu, D.Y. Bacterial lipopolysaccharide, phorbol myristate acetate, and muramyl dipeptide stimulate the expression of a human monocyte surface antigen, Mo3e. J. Immunol. 135, 3869, 1985.

23. Todd, R.F. III, Bury, M.B., Alvarez, P.A., Brott, D.A., and Liu, D.Y. Regulation of human monocyte surface antigen expression. I. Up-modulation of Mo3e antigen expression of U-937 and HL-60 cells stimulated by pharmacologic activators of protein kinase C. Blood 68, 1154, 1986.

24. Todd, R.F. III, Griffin, J.D., Ritz, J., Nadler, L.M., Abrams, T., and Schlossman, S.F. Expression of normal monocyte-macrophage differentiation antigens on HL-60 promyelocytes undergoing differentiation induced by leukocyte conditioned medium or phorbol diester. Leuk. Res. 5, 491, 1981.

25. Todd, R.F. III, and Liu, D.Y. Mononuclear phagocyte activation: Activation associated antigens. Fed. Proc. 45, 779, 1986.

26. Todd, R.F. III, Nadler, L.M., and Schlossman, S.F. Antigens on human monocytes identified by monoclonal antibodies. J. Immunol. 126, 1435, 1981.

27. Todd, R.F. III, Schlossman, S.F. Analysis of antigenic determinants on human monocytes and macrophages. Blood 59, 775, 1982.

28. Towbin, H., Staehelin T., and Gordon J. Electrophoretic transfer of proteins from polyacrylamide gels to nitrocellulose sheets: Procedure and some applications. Proc. Natl. Acad. Sci. U.S.A. 76, 4350, 1979.

29. Vandenbark, G.R., Kuhn, L.J., and Niedel, J.E. Possible mechanism of phorbol diester-induced maturation of human promyelocytic leukemia cells. J. Clin. Invest. 73, 448, 1984.

30. Yam, L.T., Li, C.Y., and Crosby, W.H. Cytochemical identification of monocytes and granulocytes. Am. J. Pathol. 55, 283, 1971. 